\title{
AKTIVITAS ENZIM PEROKSIDASE BAWANG MERAH YANG DIINTRODUKSI DENGAN BAKTERI ENDOFIT DAN TAHAN TERHADAP PENYAKIT HAWAR DAUN BAKTERI (XANTHOMONAS AXONOPODIS PV. ALLII)
}

\author{
Zurai Resti ${ }^{1}$, Trimurti Habazar ${ }^{1}$, Deddi Prima Putra $^{2}$, \& Nasrun ${ }^{3}$ \\ ${ }^{1}$ Program Studi Agroekoteknologi, Fakultas Pertanian, Universitas Andalas \\ ${ }^{2}$ Fakultas Farmasi Universitas Andalas \\ Kampus Unand Limau Manis, Padang \\ ${ }^{3}$ Balai Penelitian Tanaman Obat dan Aromatik, Laing, Solok \\ E-mail: zures_01@yahoo.com
}

\begin{abstract}
Peroxidase enzyme activity of the introduced shallots with endophytic bacteria and resistant to bacterial leaf blight (Xanthomonas axonopodis pv. allii). Bacterial leaf blight caused by Xanthomonas axonopodis pv. allii is an important disease in shallots. We have earned six isolates of endophytic bacteria, which have the ability to induce systemically resistance to shallots. One mechanism in induce resistance in plants is a change in the plant defense enzyme activity such as peroxidase. The purpose of this study was to calculate the peroxidase enzyme activity of shallots crop is being introduced with endophytic bacteria and is able to induce resistance to Xanthomonas axonopodis pv. allii. This research was conducted by introducing six isolates of endophytic bacteria on shallot bulbs and planted in greenhouse. Shallots crop that was 14 days old then inoculated with the bacterium Xanthomonas axonopodis pv. allii and incubated until symptoms appear. Peroxidase enzyme activity was calculated on the roots and leaves of shallots are $0,1,2,4,6,8,10,15$, and 30 days after inoculation (dai). The results showed an increase in the peroxidase enzyme activity of shallots crop is being introduced by endophytic bacteria compared to the control. Isolates ULG1E2 (Serratia marcescens PPM4) was isolate with the highest peroxidase enzyme activity both in the roots and leaves are $0,051 \mathrm{im} / \mathrm{ml}$.
\end{abstract}

Key words: endophytic bacteria, Shallot, peroxidase enzyme, Xanthomonas axonopodis pv. allii

\begin{abstract}
ABSTRAK
Aktivitas enzim peroksidase bawang merah yang diintroduksi dengan bakteri endofit dan tahan terhadap penyakit hawar daun bakteri (Xanthomonas axonopodis $p v$. allii). Penyakit hawar daun bakteri yang disebabkan oleh Xanthomonas axonopodis pv. allii merupakan penyakit yang penting pada pertanaman bawang merah. Penulis telah mendapatkan enam isolat bakteri endofit, yang memiliki kemampuan mengimbas ketahanan tanaman bawang merah secara sistemik. Salah satu mekanisme dalam pengimbasan ketahanan pada tanaman adalah perubahan aktivitas enzim pertahanan tanaman seperti peroksidase. Tujuan penelitian ini adalah menghitung aktivitas enzim peroksidase dari tanaman bawang merah yang diintroduksi dengan isolat bakteri endofit dan mampu mengimbas ketahanannya terhadap Xanthomonas axonopodis pv. allii. Penelitian ini dilakukan dengan mengintroduksikan enam isolat bakteri endofit pada umbi bawang merah dan ditanam di rumah kaca. Tanaman bawang merah yang berumur 14 hari kemudian diinokulasi dengan bakteri Xanthomonas axonopodis pv. allii dan diinkubasi sampai muncul gejala. Aktivitas enzim peroksidase dihitung pada akar dan daun tanaman bawang merah yang berumur $0,1,2,4,6,8,10,15$, dan 30 hari setelah inokulasi (hsi). Hasil penelitian menunjukkan terjadinya peningkatan aktivitasenzim peroksidase pada tanaman bawang merah yang diintroduksi bakteri endofit dibandingkan dengan kontrol. Isolat $\mathrm{ULG}_{1} \mathrm{E}_{2}$ (Serratia marcescens PPM4) merupakan isolat dengan aktivitas enzim peroksidase tertinggi baik pada akar maupun daun yaitu $0,051 \mu \mathrm{m} / \mathrm{ml}$.
\end{abstract}

Kata kunci: bakteri endofit, bawang merah, enzim peroksidase, Xanthomonas axonopodis pv. allii 


\section{PENDAHULUAN}

Penyakit hawar daun bakteri (HDB) yang disebabkan oleh bakteri Xanthomonas axonopodis pv. allii (Xaa) merupakan penyakit penting yang dapat menyerang berbagai jenis bawang (Roumagnac et al., 2004). Gejala ditemukan pada daun berupa bintik kecil kebasahan yang kemudian meluas menjadi coklat kehitaman, gejala ini kemudian menyatu menyebabkan terjadinya gejala mati pucuk serta hawar pada daun-daun yang lebih tua (Paulraj \& O'Garro, 1993). Kerusakan akibat gejala penyakit dapat menurunkan hasil dan kualitas umbi (mencapai 100\%) bila kondisi lingkungan mendukung dengan suhu dan curah hujan yang tinggi (Schwart \& Gent, 2006).

Xanthomonas axonopodis pv. allii mempunyai banyak inang, tidak saja dari spesies Alliium spp. seperti bawang Bombay (Alliium cepa), bawang putih (Alliium saliviat $\mathrm{L}$.), bawang daun (Alliium fistulosum), bawang merah (Alliium ascolonicum), tetapi juga menyerang tanaman leguminosa seperti buncis (Phaseolus vulgaris. L), kedelai (Glycine max), kacang lima (Phaseolus lunatus), dan Pisum sativum (Schwartz \& Gent, 2006). Penyebaran patogen melalui air irigasi, kultur teknis yang tidak baik, sisa tanaman terserang setelah panen, serta benih yang terkontaminasi. Patogen ini termasuktularbenih (seed-born) (Roumacnag et al., 2004).

Patogen ini sangat sukar dikendalikan, sebagian besar pengendalian yang dilakukan menggunakan pestisida. Penggunaan pestisida harus diminimumkan karena dampak negatifnya terhadap manusia dan lingkungan. Pengendalian hayati merupakan salah satu alternatif pengendalian yang dapat menekan penggunaan bahan kimia pada budidaya tanaman pertanian (De Weger et al.,1995; Postma et al., 2003).

Bakteri endofit adalah bakteri yang berada dalam jaringan tanaman dan keberadaannya dalam jaringan tanaman tersebut tidak menimbulkan kerusakan dan tidak menimbulkan gejala apapun bagi tanaman. Bakteri endofit ini dapat diisolasi dari akar, batang, daun, bungan dan kotiledon (Bandara et al.,2006). Bakteri endofit dapat berperan sebagai pemacu pertumbuhan tanaman (Barka et al.,2002), mengurangikeparahanpenyakit (Kloepper et al., 2004), mengimbas ketahanan tanaman (Bakker et al., 2007), menghasilkan senyawaanti-herbivory (Sullivan et al., 2007), membantu penyerapan nitrogen (Jha \& Kumar, 2007) dan meningkatkan penyerapan mineral bagi tanaman (Molinowski et al., 2000). Di dalam tanaman bakteri endofit dapat terlokalisir pada bagian dimana bakteri tersebut mulai masuk atau menyebar ke bagian tanaman lainnya. Di dalam jaringan tanaman bakteri berada di dalam sel, di ruang antarsel atau dalam jaringan pembuluh (Zinniel et al.,2002). Bakteri endofit sebagai agens biokontrol memiliki kelebihan dibandingkan agen biokontrol lainnya karena keberadaannya dalam jaringan tanaman, membuatnya mempunyai kemampuan bertahan terhadap tekanan biotik dan abiotik (Hallman et al.,1997).

Beberapa jenis bakteri endofit di samping sebagai agens biokontrol, juga sebagai pemacu pertumbuhan tanaman, dan meningkatkan ketahanan tanaman terhadap patogen seperti Pseudomonas cepacia, Pseudomonas fluorescens, dan Bacillus sp (Kloepper et al.,1999). Burkholderia sp. Strain PsJN mampu memacu pertumbuhan tanaman anggur (Vitis vinifera L.) (Compant et al.,2004). Informasi terbaru menyatakan bahwa Pseudmonad fluoresens bersifat endofit pada perakaran padi dan mampu memfiksasi Nitrogen (Centre for Microbial and Plant Genetics, 2006). Bakteri endofit Bacillus spp. yang berasal dari berbagai jenis sayuran mampu megurangi keparahan penyakit busuk buah pada tanaman coklat (Melnick et al.,2008). Pseudomonas putida 89B-27 dan Serratia marcesscen 90-166 menguranggi serangan Cucumber Mosaic Virus pada tomat dan mentimun (Raupach et al., 2000), juga mengurangi serangan antraknos dan layu Fusarium pada mentimun (Liu et al.,1995). Pseudomonas sp. strain PsJN menghambat Botrytis cinerea pada bawang dan memacu pertumbuhan anggur (Barka et al.,2002). Penulis telah berhasil mendapatkan enam isolat bakteri endofit, yang mempunyai kemampuan mengimbas ketahanan bawang merah secara sistemik terhadap Xanthomonas axonopodis pv. allii. Hasil identifikasi secara molekular enam isolat tersebut adalah Bacillus cereus strain P14, Bacillus cereus strain Se07, Bacillus sp H1, Bacillus sp SJ1, dan dua bakteri Serratia marcescens strain PPM4 (Resti et al., 2013).

Ketahanan konstitutif tanaman secara struktural termasuk adanya penghambat (barrier) seperti dinding sel, juga senyawa penghambat seperti senyawa fenol (Nurnberger et al., 2004). Enzim peroksidase berperan sebagai katalis dalam polimerasi monolignol yang membangun dinding sel tanaman (Vidhyaserakan, 2004). Infiltrasi lignin di dalam ruang dinding sel dapat meningkatkan kekuatan mekanik sel tanaman terhadap penetrasi patogen (Huang, 2001; Strange, 2003). Peroksidase adalah enzim yang berperan dalam proses ketahanan tanaman termasuk reaksi hipersensitif, proses lignifikasi, sintesis fenol, glycoprotein, penggabusan dan produksi fitoaleksin (Nicholson\& Hummerschmidt, 1992; Wojtaszek, 1997). Tujuan penelitian ini, adalah menghitung aktivitas enzim peroksidase pada bawang 
merah yang diintroduksi dengan isolat bakteri endofit dan mampu mengimbas ketahanan terhadap Xanthomonas axonopodis pv. allii.

\section{METODE PENELITIAN}

Tempat dan Waktu. Penelitian dilaksanakan di Laboratorium Bakteriologi Jurusan Hama dan Penyakit Tumbuhan dan rumah kaca Fakultas Pertanian Universitas Andalas Padang. Penelitian berlangsung dari April sampai Oktober 2013.

Bahan Tanaman. Benih bawang merah (kultivar Medan) diperoleh dari petani menangkar benih di daerah Alahan Panjang Kabupaten Solok, Sumatera Barat. Tanaman bawang merah dipelihara di rumah kaca Fakultas Pertanian Universitas Andalas Padang.

Isolat Bakteri Endofit. Enam isolat bakteri endofit yang digunakan pada penelitian ini merupakan isolat terbaik dalam pengimbasan ketahanan tanaman bawang merah terhadap penyakit hawar daun bakteri (Xanthomonas axonopodis pv. allii). Isolat ini diisolasi dari perakaran tanaman bawang merah sehat yang berasal dari dua Kabupaten di Sumatera Barat yaitu Kabupaten Solok dan Kabupaten Agam. Isolat bakteri endofit yang digunakan yaitu SN1E4 (Bacillus sp H1), SN2E2 (Bacillus cereus strain Se07), PU2E2 (Bacillus sp SJ1), BD4.2E1 (Bacillus cereus Strain P14), JB1E3 dan ULG1E2 (Serratia marcescens strain PPM4).

Introduksi Bakteri Endofit pada Benih Bawang Merah. Benih bawang merah kultivar Medan di potong $1 / 3$ bagian atasnya dan direndam dengan suspensi bakteri endofit $\left(10^{8} \mathrm{sel} / \mathrm{ml}\right)$ selama 15 menit untuk menyakinkan bahwa suspensi bakteri menempel di permukaan benih. Pada perlakuan kontrol, benih direndam dalam akuades steril (Resti et al., 2013). Benih ditanam pada media tanah steril (perbandingan tanah dan pupuk kandang 3:1), tanpa pemberian pupuk buatan dan tanaman disiram setiap hari.

Inokulasi Xanthomonas axonopodis pv. allii. Setelah tanaman berumur 14 hari, bakteri patogen diinokulasikan dengan metode pelukaan daun menggunakan jarum steril. Suspensi bakteri Xanthomonas axonopodis pv. allii $\left(10^{6}\right.$ $\mathrm{sel} / \mathrm{ml}$ ) dioleskan pada bagian ujung daun bawang merah yang telah dilukai (Klement et al., 1990). Tanaman bawang merah yang telah diinokulasi selanjutnya disungkup dengan plastik bening, diamati tiap hari sampai muncul gejala kebasahan. Tanaman dipanen bagian akar dan daunnya pada umur, $0,1,2,4,6,8,10,15$, dan 30 hari setelah inokulasi (hsi).

Analisis Aktivitas Enzim Peroksidase. Sampel daun dan akar segar ditimbang sebanyak 1 g kemudian dihancurkan dengan mortar setelah ditambahkan segera $2,5 \mathrm{ml} 0,5 \%$ dapar kalium posfat $\mathrm{pH} 7$ dan 0,1 gram PVP (Polyvinyl pyrnplidone). Campuran tersebut diambil ekstraknya dan disaring dengan dua lapis kain kassa, disentrifus dengan kecepatan 6.000 rpm selama 15 menit pada suhu $4^{\circ} \mathrm{C}$. Supernatan tersebut dipakai untuk pengukuran aktivitas peroksidase.Pengukuran aktivitas enzim peroksidase menggunakan metode Bateman (1967). Ekstraksi enzim sebanyak 0,2 ml dimasukkan ke dalam kuvet yang telah berisi $5 \mathrm{ml}$ larutan pirogalol $(0,631 \mathrm{~g}$ pirogalol dalam dapar fosfat $0,005 \mathrm{M}$ pH 6 volume akhir $100 \mathrm{ml}$ ) kemudian dikocok. Kuvet diletakkan pada rppektrofotometer (Mapada V.1100 D spectrophotometer) diatur agar jarum menunjukkan absorban yang sama dengan angka nol pada panjang gelombang $420 \mathrm{~m}$. Kuvet diangkat dan ditambah 0,5 $\mathrm{ml} \mathrm{H}_{2} \mathrm{O}_{2} 1 \%$ kemudian dikocok dan segera diletakkan pada spektrofotometer. Perubahan absorban diamati setiap 5 detik, sampai tidak terjadi perubahan lagi. Aktivitas Peroksidase dinyatakan dalam satuan $\mu \mathrm{g} / \mathrm{ml}$.

\section{HASIL DAN PEMBAHASAN}

Aktivitas enzim peroksidase pada akar dan daun bawang merah dihitung setelah tanaman diintroduksi dengan bakteri endofit dan diinokulasi dengan bakteri patogen (Xanthomonas axonopodis pv. allii). Aktivitas peroksidase pada daun dan akar bawang merah yang diintroduksi dengan bakteri endofitterus meningkat mulai dari 0 hsi (hari setelah inokulasi) sampai 10 hsidibandingkan kontrol. Enzim peroksidase pada akar (Gambar 1) lebih tinggi aktivitas dibandingkan pada daun (Gambar 2). Isolat $\mathrm{ULG}_{1} \mathrm{E}_{2}$ merupakanisolat bakteri endofit dengan aktivitas peroksidase tertinggi pada 10 hsi yaitu $0,051 \mu \mathrm{g} / \mathrm{ml}$ pada akar maupun daun.

Ketika tanaman terinfeksi patogen akan terjadi perubahan fisiologi pada tanaman, dan enzim pertahanan tanaman umumnya akan aktif bereaksi. Enzim peroksidase merupakan salah satu enzim yang berhubungan dengan proses pertahanan tanaman. Terbentuknya pertahanan akibat aktivitas enzim periksodase ditentukan oleh kepekaan tanaman terhadap suatu penyakit. Ketahanan konstitutif tanaman secara struktur termasuk adanya penghambat (barrier) seperti dinding sel, juga senyawa penghambat seperti senyawa fenol (Nurnberger et al., 2004). Peroksidase adalah enzim 


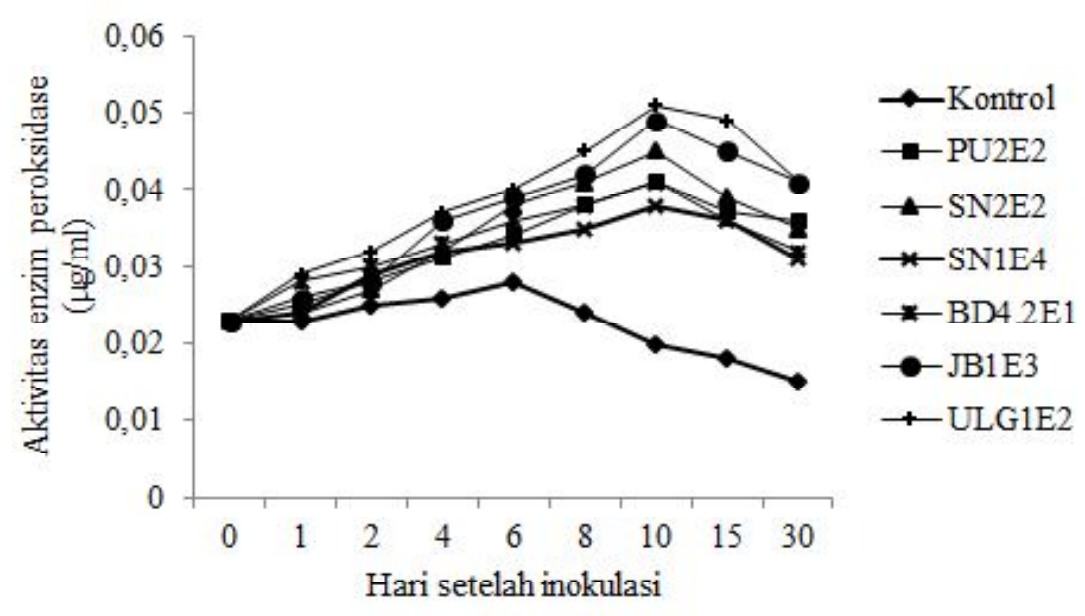

Gambar 1. Aktivitas peroksidase pada akar bawang merah yang telah diintroduksi dengan bakteri endofit dan diinokulasi dengan Xanthomona axonopodis pv. allii

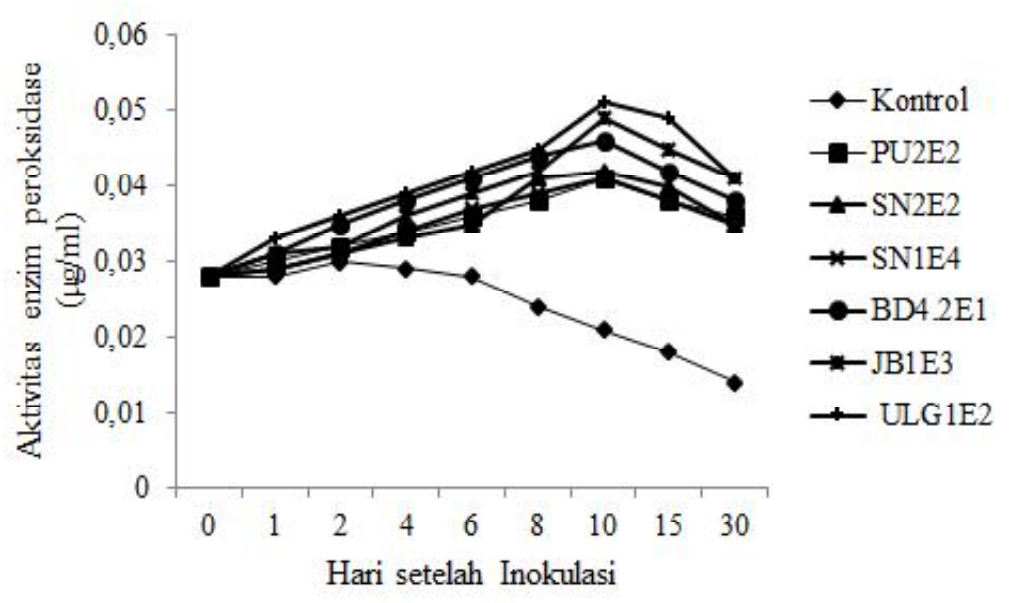

Gambar 2. Aktivitas peroksidase pada daun bawang merah yang diintroduksi dengan bakteri endofit dan diinokulasi dengan Xanthomona axonopodis pv. allii

yang berperan dalam proses ketahanan tanaman termasuk reaksi hipersensitif, peligninan, sintesis fenol, glycoprotein, penggabusan dan produksi fitoaleksin (Nicholson \& Hummerschmidt, 2002; Wojtaszek, 1997).

Peningkatan aktivitas enzim peroksidase pada tanaman bawang merah yang diintroduksi dengan bakteri endofit merupakan salah satu petunjuk terjadinya pengimbasan ketahanan tanaman terhadap patogen, dengan penurunan tingkat keparahan penyakit. Penelitian Resti et al. (2013) membuktikan bahwa introduksi bakteri endofit $\mathrm{ULG}_{1} \mathrm{E}_{2}$ pada tanaman bawang merah menurunkan persentase keparahan penyakit sampai $17,28 \%$. Aktivitas peroksidase lebih tinggi pada tanaman yang diintroduksi dengan bakteri endofit dibandingkan kontrol. Peningkatan tertinggi terjadi pada tanaman yang diintroduksi dengan isolat bakteri endofit $\mathrm{ULG}_{1} \mathrm{E}_{2}$ yaitu
$0,051 \mu \mathrm{g} / \mathrm{ml}$, diikuti oleh isolat $\mathrm{JB}_{1} \mathrm{E}_{3}$ yaitu $0,049 \mu \mathrm{g} / \mathrm{ml}$, isolat $\mathrm{BD}_{4 \cdot 2} \mathrm{E}_{1}$ yaitu $0.046 \mu \mathrm{g} / \mathrm{ml}$, isolat $\mathrm{SN}_{2} \mathrm{E}_{2}$ yaitu 0,042 $\mu \mathrm{g} / \mathrm{ml}$, isolat PU2E2 dan $\mathrm{SN}_{1} \mathrm{E}_{4}$ yaitu $0,041 \mu \mathrm{g} / \mathrm{ml}$ serta kontrol 0,021 $\mu \mathrm{g} / \mathrm{ml}$ (Gambar 1). Menurut Resti et al. (2013), isolat $\mathrm{ULG}_{1} \mathrm{E}_{2}$ dan $\mathrm{JB}_{1} \mathrm{E}_{3}$ secara molekular merupakan bakteri Serratia marcescens $\mathrm{PPM} 4, \mathrm{PU}_{2} \mathrm{E}_{2}$ merupakan Bacillus sp SJI, $\mathrm{SN}_{1} \mathrm{E}_{4}$ merupakan Bacillus sp $\mathrm{HI}, \mathrm{SN}_{2} \mathrm{E}_{2}$ merupakan Bacillus cereus $\mathrm{Se} 07$ dan $\mathrm{BD}_{4.2} \mathrm{E}_{1}$ merupakan Bacillus cereus $\mathrm{P} 14$. Hal ini menunjukkan bahwa introduksi umbi bawang merah dengan bakteri endofit dari kelompok Bacillus dan Serratia marcescens dapat meningkatkan ketahanan tanaman bawang merah terhadap penyakit hawar daun bakteri. Isolat $\mathrm{ULG}_{1} \mathrm{E}_{2}$ memiliki aktivitas peroksidase tertinggi baik pada akar maupun daun $(0,051 \mu \mathrm{m})$. Isolat ini secara molekulartermasuk ke dalam spesies Serratia 
marcescens yang merupakan kelompok bakteri endofit dan mampu mengimbas ketahanan tanaman terhadap patogen.serratia marcescens dikenal sebagai bakteri endofit yang diisolasi dari bawang merah (Edward et al., 1989) dan dapat mengimbas ketahanan tanaman arabidopsis terhadap Cucumber Mosaic Virus (Ryu et al., 2003). Serratia marcesscen 90-166 mengurangi serangan Cucumber Mosaic Virus pada tomat dan mentimun (Raupach et al., 1996), juga mengurangi gejala penyakit antraknos dan layu fusarium pada mentimun (Liu et al.,1995). Bakterisasi dengan Serratia marcescens NBRI1213 meningkatkan aktifitas enzim Peroksidase pada daun dan akar tanaman sirih yang tahan terhadap Phytopthora nicotiana (Lavania et al., 2006).

Aktivitas peroksidase berkaitan dengan mekanisme peligninan pada dinding sel tanaman dan produksi senyawa fenol. Dinding sel yang kuat akan menghalangi proses masuknya patogen pada saat infeksi. Menurut Silva et al.(2004), aktivitas peroksidase dapat menghambat proses infeksi patogen karena terjadinya peligninan yang menghambat patogen masuk. Introduksi Pseudomonas fluorescens CHAO pada tanaman tomat yang mampu menekan Fusarium oxysporumf sp. lycopersici dapat meningkatkan aktivitas enzim peroksidase (Ardebili et al., 2011). Penumpukan enzim peroksidase, Polyphenol Oksidase, dan Phenyl almine lyase pada akar pisang yang tahan terhadap Fusarium oxysporum f.sp. cubense dan diintroduksi dengan Pseudomonas fluorescens menunjukkan terjadinya pengimbasan pertahanan pada pisang (Saravanan et al., 2004). Aktivitas enzim peroksidase secara nyata meningkat pada tanaman mentimun yang diperlakukan dengan Bacillus substilis B579 (Chen et al., 2010).

Pada kontrol juga terjadi aktivitas peroksidase sampai hari ke-6 hsi, dan kemudian terus turun. Hal ini terjadi karena reaksi tanaman terhadap infeksi patogen, pelukaan daun saat inokulasi patogen. Menurut Van Loon (1997) enzim peroksidase merupakan suatu kelompok PR-protein (Pathogenesis-Related protein) dari golongan PR-9 yang terkumpul pada saat tanaman sakit. Selain itu, peningkatan aktivitas enzim peroksidase dipengaruhi oleh adanya serangan patogen. Aktivitas peroksidase sebagai penanda terjadinya pengimbasan yang bersifat lokal maupun sistemik pada tanaman (Martinez et al., 2000).

\section{SIMPULAN}

Hasil penelitian menunjukkan terjadinya peningkatan aktivitas enzim peroksidase pada tanaman bawang merah yang diintroduksi bakteri endofit dibandingkan dengan kontrol. Isolat $\mathrm{ULG}_{1} \mathrm{E}_{2}$ (Serratia marcescensPPM4) merupakan isolat dengan aktivitas enzim peroksidase tertinggi baik pada akar maupun daun yaitu $0,051 \mu \mathrm{m} / \mathrm{ml}$.

\section{SANWACANA}

Ucapan terima kasih disampaikan kepada Ibu Dr. Yulmira Yanti, S.Si., M.P. atas saran dan bantuannya dalam penelitian ini.

\section{DAFTAR PUSTAKA}

Ardebili ZO, Ardebili NO, \& Hamdi SMM. 2011. Physiological effects of Pseudomonas fluorescens $\mathrm{CHA} 0$ on tomato (Lycopersicum esculentum Mill) plants and its possible impact on Fusarium oxysporum f.sp lycopersici. Australian J. Crop Sci. (AJCS) 5(12): 16311638.

Bakker PAHM, Pierterse CMJ, \& van Loon LC. 2007. Induced systemic resistance by Fluorescent Pseudomonas spp. Phytopathology 97(2): 239243.

Bandara WM, Seneviratne G, \& Kalasooriya SA. 2006. Interaction among endophytic bacteria and fungi: effects and potensials. Indian AcademY and Sciences. J. Biosci 31(5): 645-650.

Barka EA, Gognies S, Nowak J, Audran JC, \& Belarbi A. 2002. Inhibitory effect of endophyt bacteria on Botrytis cinerea and its influence to promote the grapevine growth. Biol. control 24(2): 135142.

Centre for Microbial and Plant Genetics. 2006. Plant Growth Promoting Rhizobacteria dan Biodegradasi. Katolike Universiteit Leuwen, Netherlan.

Chen F, Wang M, Zheng Y, Luo J, Yang X, \&Wang X. 2010. Quantitative changes of plant defense enzymes and phytohormone in biocontrol of cucumber Fusarium wilt by Bacillus subtilis B579. World. J. Microbiol Biotechnol. 26: 675684.

Compant S, Reiter A, Sessitsch A, Nowak J, Clement C, \& Barka EA. 2004. Endophytic colonization of Vitis vinifera L. by plant growth promoting bacterium Burkholderia sp. strain PsJN. Appl. Environ. Microbiol 71(4): 1685-1693. 
de Weger LA, van Der Bij AJ, Dekkers LC, Simons M, Wijffelman CA,\& Lugtenberg BJJ. 1995. Colonization of the rhizosphere of crop plants by plant-beneficial Pseudomonads FEMS Microbiol. Ecol. 17: 221-228.

Hallmann J, Quadt- Hallmann QA, Mahaffee WF, \& Kloepper JW. 1997. Bacterial endophytes in agricultural crops. Can. J. Microbiol. 43(10): 895-914.

Huang JS. 2001. Plant Pathogenesis and Resistance : Biochemestry and Physiology of PlantMicrobe interaction. Kluwer academic Publisher, Netherland.

Jha PN \& Kumar A. 2007. Endophytic colonization of Typha australis by a plant growth-promoting bacterium Klebsiella oxytoca strain GR-3. J. Appl. Microbiol. 103(4): 1311-1320.

Kloepper JW, Leong J, Teintze M, \& Schoth MN. 1999. Enhanced plant growth by sideophores produced by plant growth-promting rhizobacteria. Nature. 286: 885-886.

Kloepper JW, Ryu CM, \& Zhang S. 2004. Induced systemic resistance and promotion of plant growth by Bacillus spp. Phytophatology 94(11): 12591266.

Lavania M, Cauhan PS, Chauhan SVS, Singh HB, \& Nautiyal CS. 2006. Induction of plant defense enzymes and phenolics by treadment with Plant Growth-Promoting Rhizobacteria Serratia marcescens NBRI1213. Current Microbiology 52: 363-368

Liu L, Kloepper JW, \& Tuzun S. 1995. Induction of systemic resistance in cucumber against Fusarium wilt by plant growth promoting rhizobacteria. Phytopathology 85(6): 695-698.

Martinez C, Baccou JC, Bresson E, Baissac Y, Daniel JF, Jalloul A, Montillet JL, Geiger JP, Assigbetse \& Nicole M. 2000. Salysilic acid mediated by the oxidative burst in a key molecule in local and systemic responses of cotton challenged by an avirulent race of Xanthomonas campestris pv malvacearum. Plant Physiol. 122: 757-766.

Melnick RL, Zidack NK, Bailey BA, Maximova SN, Guiltinan M, \& Backman PA. 2008. Bacterial endophytes: Bacillus spp. from annual crops as potential biological control agents of black pod rot of cacao. Biol. control 46(1): 46-56.
Nicholson RI \& Hammerschmidt R 2002. Phenolic compounds and their role in disease resistance. Annual Review of Phytophatology 30: 369-389.

Numberger T, Brunner F, Kemmerling B, \& Plater. 2004. Innate immunity in plant and animal: Striking similarities and obvius differences. Innunol.Rev. 198: 249-266.

Paulraj L, \& O'Garro LW. 1993. Leaf Blight of Onion in Barbados Caused By Xanhomonas campestris. Plant Dis. 86: 3330.

Postma J, Montanari M, \&Van Den Boogert PHJF. 2003. Microbial enrichment to enhance the disease suppressive activity of compost. Eur.J. Soil Biol. 39:157-163.

Roumagnac P, Pruvost O, Chiroleu F, \& Hughes H. 2004. Spatial ann temporal analysis of bacterial blight of onion caused by Xanthomonas axonopodis pv allii. Phytophatology 94: 138146.

Raupach GS \& Kloepper JW. 2000. Biocontrol of cucumber diseases in the field by plant growth promoting rhizobacteria with and without methyl bromide fumigation. Plant Dis. 84:1073-1075

Resti Z, Habazar T, Putra DP, \& Nasrun. 2013. Skrining dan identifikasi isolat bakteri endofit untuk mengendalikan penyakit hawar daun bakteri pada bawang meah. JHPT Tropika 13(2): 1167-1178.

Ryu CM, Farag MA, Hu CH, Reddy MS, Wei HX, Pare PW, \& Kloepper JW. 2003. Bacterial volatiles promote growth in Arabidopsis. Pr. Natl. Acad. Sci USA. 100(8): 4927-4932.

Saravanan T, Bhaskaran R, \& Muthusamy M. 2004. Pseudomonas fluorescens induced enzymatological changes in banana roots (cv. Rasthali) again Fusarium wilt disease. Plant Pathology. J. 3(2): 72-80.

Schwartz HF \& Gent DH. 2006. Xanthomonas Leaf Blight of Onion http//www.Extcolestate.edu/push/ gorden html Access 22-02-2006.

Silva HAS, Romeiro RS, \& Macagnan D. 2004. Rhizobacterial indiction of systemic resistance in tomato plant: non-specific protection and increase in enzyme activities. Biol. Control. 29(2): 288295. 
Sullivan TJ, Rodstrom J, Vandop J, Librizzi J, Graham C, Schardi CL,\& Bultman TL. 2007. Symbiontmediated changes in Lolium arundinaceum inducible defense: evidence from changes in gene expression and leaf composition. New phytologist 176(3): 673-679.

Strange RN. 2003. Introduction to Plant Pathology. John Willey and Sons Ltd, England.

Van Loon. LC. 1997. Induced resistance in plants and the role of pathogenesis-related proteins. Evr. $J$. Plant Phatol. 103: 753-765.

Vidhyasekaran, P. 2004. Concise Enclycolpedia of Plant Pathology. Food Product Press and Howard Reference Press, London.
Wojtaszek P. 1997. The oxidative burst : an early plant response to pathogen infection. Biochem. J. 322 (Pt 3): 681-692.

Zinniel DK, Lambrecht P, Harris NB, Feng Z, Kuczmarski D, Higley P, Ishimaru CA, Arunakumari A, Barletta RG, \& Vidaver AK. 2002. Isolation and characterization of endophytic colonizing bacteria from agronomic crops and prairie plants. Appl. Environ. Mycrobiol. 68(5): 2198-2208. 